\title{
Lars Dencik
}

\section{Antisemitisms in the Twenty-First Century}

\section{Sweden and Denmark as Forerunners?}

\begin{abstract}
This article deals with antisemitism in Europe and post-Holocaust Sweden and Denmark specifically. The idea that it is always "the same old antisemitism" that pops up and "shows its ugly face" does not find support in this study. Instead, we distinguish between three different kinds of contemporary antisemitisms: Classic antisemitism, Aufklärungsantisemitismus, and Israel-derived antisemitism. Our findings suggest that each of these antisemitisms is inspired by different underlying "philosophies," and that they are carried by different social groups and manifested in different ways.

In the Scandinavian countries today, we find that there is less classic antisemitism, much more Aufklärungsantisemitismus, and a relatively stronger presence of Israel-derived antisemitism. In our analysis this specifically Scandinavian pattern of antisemitisms is closely related to the highly developed processes of modernization in the Scandinavian countries on the one hand and the relatively large numbers of recently arrived immigrants from the Middle East on the other. This appears to imply that antisemitism based on racial prejudices is losing ground, as is antisemitism based on religious convictions. However, according to the European Union Agency For Fundamental Rights (FRA) in Antisemitism: Overview of Data Available in the European Union 2007-2017 (Luxembourg: Luxembourg Publications Office of the European Union, 2018), the incidence of violent antisemitic attacks seems to be on the rise. These typically emanate from small pockets of individuals in the population who share an image of all Jews being accomplices to whatever the State of Israel does.

Considering how the processes of modernization operate it is assumed that other countries in Europe will follow a similar trajectory. Rationalization, secularization, and individuation will also come to penetrate these societies and weaken notions of "race" and "religion" as springboards for antisemitism. Thus, tendencies towards Aufklärungsantisemitismus will be strengthened. If integrating and getting rid of the marginalization and condescending treatment of its newly arrived Muslim inhabitants does not succeed, Israel-derived antisemitism can be expected to thrive. The pattern of antisemitisms in Denmark and Sweden might be a preview of what antisemitisms in twenty-first-century Europe could come to look like.
\end{abstract}


Keywords: Antisemitism; Aufklärungsantisemitismus; brit milah; Denmark; European Agency for Fundamental Rights; Holocaust; immigration; modernization; shechita; Sweden.

It is sometimes said that Jews are like any other persons - just more so. When it comes to modern antisemitism, the Scandinavian countries are likewise just like any other European country - just more so. Do not misunderstand! It is not that there is more antisemitism in the Scandinavian countries today than in Europe in general - indeed, the opposite appears to be the case - but rather that ongoing transformations in the patterns of antisemitism, changes which have to do with deeper tendencies in social and political developments in Europe - have gone further in the Scandinavian countries than they have in Europe in general.

Antisemitism is always a matter of prejudices about and animosity towards Jews. But antisemitism is still not a coherent and stable body of attitudes about Jews. Reviewing the history of antisemitism in Europe we find that antisemitism in some epochs was mainly based on religious ideas, with Jews being seen as traitors who did not believe in Jesus of Nazareth as the Messiah and who should be blamed for having killed him; in other epochs antisemitism was instead fed by political ideas, with Jews being seen as strangers who did not belong to the people with a birthright in their nation-state; we also have epochs when the idea of Jews as controllers, abusers, and exploiters of the economy surfaced as the predominant form of antisemitism; the Shoah that destroyed European Jewry in the first part of the twentieth century was, however, mainly based on racist biological ideas of Jews as a degenerate people whose very existence constituted a disease within the human body. Accordingly, this racist idea commanded the Jew be extinguished - both individually and as a people.

Behind these diverse aspects of antisemitism there usually lies a mental construction of a Jewish conspiracy of some kind. Even if it may not be quite obvious to the antisemite what Jews are really up to, how they actually killed the Christian Messiah, infiltrated the nations of the world, run the world economy, or are in fact a racially degenerate people, etc. - just this, the very fact that this is obscure, makes the antisemite even more convinced that somehow there must be some kind of a secret (world) conspiracy behind it all.

So, what is the predominant image of a secret Jewish world conspiracy in the Scandinavian countries today? Here are two background examples:

1. Late at night on 15 February 2015, a bat mitzvah party took place in the Jewish cultural centre where the main synagogue is also located in Copenhagen. 
About eighty people, most of them teenage girls, were celebrating that one of their friends had passed the symbolic threshold to become a fully independent and responsible member of the Jewish community. As part of what are now considered necessary regular security measures whenever a Jewish event takes place, thirty-seven-year-old Dan Uzan was acting as a volunteer guard outside the buildings where the festivities took place. Omar Abdel Hamid El-Hussein, a twenty-two-year-old Danish citizen with Palestinian parents, suddenly appeared and tried to get into the Jewish cultural centre behind the synagogue. Dan Uzan, unarmed but responsible for security at the entrance, blocked his path. The attacker, armed with loaded guns, shot him in the head at close range. Dan Uzan died. A few hours later El-Hussein was shot dead by a Danish police tactical unit.

It is thought that the attack might have been a copycat of the Paris attacks on the satirical magazine Charlie Hebdo and a kosher supermarket about a month before. El-Hussein might have learned of those Paris attacks while inside a Danish prison, where he was serving a two-year sentence. He had been released from prison only two weeks before his attacks. There was a suspicion that he may have become radicalized in prison like the men behind the Paris attacks. ${ }^{1}$ The head of Denmark's prison and probation service reported that authorities had noticed changes in his behaviour in prison and had alerted the intelligence services.

2. On the evening of 9 December 2017, in Gothenburg, the second largest city in Sweden, a Jewish youth organization held a Chanukah party. About forty persons were in a building adjacent to the synagogue when twelve masked men threw Molotov cocktails into the synagogue courtyard and ran away. By chance, the fire was noticed and put out before anyone was injured. Some time later the police succeeded in arresting three men: a twenty-two-yearold Palestinian from Gaza; a twenty-four-year-old Palestinian, and a nineteen-year-old Syrian. They were asylum seekers in Sweden: the latter two had been granted permanent residency status as refugees, while the man from Gaza had had his application for asylum rejected. In court they were all subsequently convicted of comitting a hate crime.

Apparently their attack on the synagogue had been provoked by the fact that President Trump had a few days previously announced that he had ordered

1 Angelique Chrisafis, "Charlie Hebdo Attackers: Born, Raised and Radicalised in Paris," The Guardian, 12 January 2015, « https://www.theguardian.com/world/2015/jan/12/-sp-charlie-hebdo-at tackers-kids-france-radicalised-paris $>$. 
that the US embassy be moved from Tel Aviv to Jerusalem, and thus by implication had also officially recognized Jerusalem as the capital of Israel.

\section{Demographics}

Before continuing we need to clarify some demographic factors. One relevant figure in this context is the absolute and relative number of Jews in the populations in question: ${ }^{2}$

Table 13.1: Jewish Population in Some Scandinavian Countries.

\begin{tabular}{lrrr}
\hline Country & Core Jewish Population & Jews per 1,000 Population & Greater Jewish Population \\
\hline Denmark & 6,400 & 1.12 & 8,500 \\
Sweden & 15,000 & 1.52 & 25,000 \\
\hline
\end{tabular}

The number of Jews living in Finland, with a population of 5.5 million, and in Norway, with a population of 5.3 million, is today considerably lower than in the two previously mentioned countries. There are slightly more than a thousand people in each of these countries who could be regarded as belonging to a core Jewish population. As can be seen above, the proportion of Jews as part of the population of the Nordic countries is very small. In Denmark and Sweden it is about the same as in today's Germany, lower than in France, Hungary, the UK, Belgium, and the Netherlands, but higher than in Poland, Spain, Italy, and Austria.

The Scandinavian countries, although similar in some significant respects, nonetheless followed very different trajectories through the Shoah. In Norway close to 40 per cent of the two thousand one hundred Jews living in the country at the time perished under the rule of the Nazi-collaborator Vidkun Quisling. At the end of September 1943, the Danish Jews learned that they too would be persecuted. In an unprecedented and unique rescue operation, almost all of them, slightly more than seven thousand, managed to escape to Sweden where they were then well received. In the 1930s until the outbreak of the Second World War, Sweden's immigration policy was very restrictive - just under three thousand Jews out of the many hundreds of thousands trying to escape Nazi perse-

2 Sergio DellaPergola, Jewish Populations in 13 European Union Countries Covered in the FRA Survey of Perceptions and Experiences of Antisemitism among Jews 2018 (London: Institute of Jewish Policy Research, 2017). 
cution in Europe were permitted entry, most of them as "political refugees." After the war, about thirteen thousand Jews were brought to Sweden from concentration camps and other places in Europe. This lay the ground for the fact that Sweden is the only country in Europe that today harbours a considerably larger Jewish population than before the Shoah. At the beginning of the 1930s there were slightly more than six thousand Jews in Sweden - today there are more than three times as many Jews in Sweden compared to when the Nazis took power in Germany. ${ }^{3}$

Other relevant demographic changes in this context have also taken place. For instance, Sweden with approximately ten million inhabitants (2018) received well over one million immigrants in the decade 2007-17, many of them from Muslim and/or Arab countries. ${ }^{4}$ In 2017, according to official statistics, 544,828 persons living in Sweden were born in or have two parents who were both born in one of the following five countries: Iran, Iraq, Lebanon, Morocco, Palestine, or Syria. To this could be added those 46,032 who by the same criteria originate from Arab countries such as Algeria, Egypt, Yemen, Jordan, Kuwait, Libya, Saudi Arabia, Tunisia, or the United Arab Emirates. If you also add those 158,759 persons who themselves come from one of the Muslim countries of Afghanistan, Bangladesh, Pakistan, or Turkey, or who were born in Sweden of two parents who both came from one of these countries, you realize that today in Sweden there are about three quarters of a million persons who in some way or another are characterized by an upbringing in Muslim and/or Arab environments. ${ }^{5}$ Which in and of itself, of course, would not be anything to focus on in this context, were it not for the fact that in more than a few such environments antisemitic tropes circulate, sometimes supported and disseminated by state-sponsored antisemitic propaganda. A similar pattern of development, albeit to a considerably lesser degree, has taken place in Denmark with its slightly less than 5.8 million inhabitants. According to official statistics from October 2018, 505,091 - i.e. just under 9 per cent of the Danish population - originate from non-Western countries, i.e. either born in such a country or the

3 Together with Jews who later escaped to Sweden in connection with the 1956 uprising in Hungary and the antisemitic policies of the communist regimes in Poland at the end of the 1960s. 4 Statiska centralbyrån (SCB) Statistikdatabasen, Invandring till Sverige, < https://www.scb.se/ hitta-statistik/sverige-i-siffror/manniskorna-i-sverige/invandring-till-sverige/ > (updated 6 November 2018).

5 SCB Statistikdatabasen, Befolkning efter födelseland 2017, « https://www.scb.se/hitta-statistik/ sverige-i-siffror/manniskorna-i-sverige/invandring-till-sverige/ >. Not since 1930 have official statistics registered religious affiliation; at that time there were fifteen Muslims living in Sweden. 
children of parents born in a non-Western country, mainly the Muslim countries Turkey, Syria, Iraq, Pakistan, and Iran. ${ }^{6}$

At this point it should be stated very clearly that the overwhelming majority of these immigrants in Scandinavia in no way engage in any kind of antisemitic acts. There is no empirical foundation for the far too easily and too often stated prejudice that Islam as a religion, or Muslims in general, constitute a threat to the welfare of Jews in Scandinavia. Nor that persons with such backgrounds do not integrate into the modern Scandinavian welfare states. For example, a survey undertaken by Als Research in Denmark shows that most socalled non-Western immigrants to Denmark have no problem accepting women's equality or homosexuals and reject the use of violence against others. The same study, however, also identifies a certain, albeit quite small, minority among these immigrants who strongly disagree on these same points, and as a result approve of the use of violence. ${ }^{7}$ Among some of the younger generations of Muslims in both Denmark and Sweden, in particular those living as marginalized inhabitants in ghetto-like areas in some of the suburbs of larger cities, there are those who have developed into criminal outlaws and some also into Salafist jihadists. ${ }^{8}$ A constitutive element of this ideology is "intolerance, discrimination, and hatred towards other groups, in particular Jews and Shia Muslims." According to the Swedish security police, the number of Islamist

6 Det nationale integrationsbarometer accessed at < https://integrationsbarometer.dk/ 〉, and Danmarks Statistik, Statistikbanken, Befolkning og Valg, Indvandrere og efterkommere FOLK1C. 7 Bjarke Følner, Sofie Aggerbo Johansen, Silas Turner, and Gustav Egede Hansen, "Undersøgelse af maskulinitetsopfattelser og holdninger til ligestilling særligt blandt minoritetsetniske mænd” [report] (Copenhagen: Als Research, 2019), « http://www.alsresearch.dk/uploads/Pub likationer/Resume_Maskulinitetsopfattelser_Als Research.pdf `. Reported in Søren Astrup, "Undersøgelse: Synet på homoseksualitet og kvinders rettigheder støder mange indvandrere,” Politiken, 25 February 2019, < https://politiken.dk/indland/art7056107/Synet-på-homoseksualitet-ogkvinders-rettigheder-støder-mange-indvandrere >

8 In more than a few cases they have become radicalized while in prison. There is a spectrum of different shades between Salafism and Salafist jihadism. In some cases, Salafism has proved to be a breeding ground for violent jihadism. Not all Salafists are jihadists, but all jihadists are Salafists.

9 Magnus Ranstorp, Filip Ahlin, Peder Hyllengren, and Magnus Normark, Mellan salafism och salafistisk jihadism: Påverkan mot och utmaningar för det svenska samhället (Stockholm: Försvarshögskolan, Centrum för totalförsvar och samhällets säkerhet, 2018), 7, 102. One of the conspiracy theories believed by some Salafists is "that the Shi'ite faith was created by a Jew who was trying to corrupt Islam from the inside." 
groups in Sweden who approve of violence has increased by a factor of ten in less than a decade. ${ }^{10}$

The Swedish Security Service estimates that around three hundred people (mostly young men, but there are also women among them) have travelled from Sweden to join jihadist groups in Iraq and Syria, especially Daesh/ISIS. ${ }^{11}$ The leading Danish daily has reported that at least twenty women from Denmark have joined Islamist groups in Syria and Iraq. ${ }^{12}$ Some of these so-called Islamic State terrorists were killed in the fighting there, however today at least 150 of them, now experienced in handling weapons and familiar with exercising brutality, are back in Sweden. ${ }^{13}$ Again, the same pattern goes for Denmark, however with lower numbers. ${ }^{14}$

\section{Antisemitisms}

Before continuing we also need to familiarize ourselves with the fact, all too often overlooked, that there are not only different degrees of antisemitism in different countries and historical epochs, but also that we can and ought to speak of and analyse different qualities or kinds of antisemitism.

In a previous study, based on data collected in 2012 in several European countries, among them Sweden, we were able to distinguish between three different kinds of antisemitism: classic antisemitism, Aufklärungsantisemitismus, and Israel-derived antisemitism.

10 Ranstorp and others, Mellan salafism och salafistisk jihadism, 7, 15; Säkerhetspolisen, "Så mycket har extremistmiljöerna vuxit,” 3 July 2017, < https://www.sakerhetspolisen.se/ovrigt/ pressrum/aktuellt/aktuellt/2017-07-03-sa-mycket-har-extremistmiljoerna-vuxit.html >.

11 In relation to its population, more people have travelled from Sweden to join these jihadist groups than from any other country in Europe with the exception of Belgium. Ranstorp and others, Mellan salafism och salafistisk jihadism, 109.

12 Jonas H. R. Moestrup, “Danske kvinder drager mot Syrien: Sådan lokker kalifatet,” TV2 Nyheder, 3 March 2019, < http://nyheder.tv2.dk/2017-03-03-danske-kvinder-drager-mod-syrien-saa dan-lokker-kalifatet >.

13 Ranstorp and others, Mellan salafism och salafistisk jihadism, 210; SVT Nyheter, 18 December 2018, « https://www.svt.se/nyheter/inrikes/sa-dalig-koll-har-kommunerna-pa-is-atervandarna `.

14 Morten Skjoldager, Truslen Indefra (Copenhagen: Lindhardt \& Ringhof, 2009). 


\section{Classic antisemitism}

This is based on classic antisemitic stereotypes such as "Jews have too much control over global affairs" and "Jews are responsible for most of the world's wars." The proportion of persons within the national populations who hold such attitudes to an extent that warrants labelling them "antisemites" is continually being measured in many countries around the world by the Anti-Defamation League (ADL). We refer to this as Classic antisemitism. ${ }^{15}$

Table 13.2: Proportion of classic antisemites in Scandinavian countries in 2014.

\begin{tabular}{|c|c|c|c|c|c|}
\hline DENMARK & $8 \%$ & NORWAY & $15 \%$ & SWEDEN & $4 \%$ \\
\hline Male & $11 \%$ & & $21 \%$ & & $4 \%$ \\
\hline Female & $6 \%$ & & $9 \%$ & & $3 \%$ \\
\hline \multicolumn{6}{|l|}{ AGE } \\
\hline $18-34$ & $7 \%$ & & $8 \%$ & & $2 \%$ \\
\hline $35-49$ & $4 \%$ & & $15 \%$ & & $1 \%$ \\
\hline $50+$ & $12 \%$ & & $20 \%$ & & $7 \%$ \\
\hline
\end{tabular}

The proportion of antisemites within the general population according to this measure is remarkably lower in Sweden than in virtually any other country in the world. The proportion of antisemites in the general population is a bit higher in Denmark and Norway than in Sweden, although even there the number is lower than in all other European countries. According to this 2014 poll, the corresponding proportion of classic antisemites is in Hungary 41 per cent, France 32 per cent, Belgium and Germany 27 per cent, and Italy 20 per cent. ${ }^{16} \mathrm{~A}$ follow-up poll conducted in 2015 in a select number of countries largely confirms this picture. Among the countries surveyed at the time, the lowest proportion, 8 per cent, was found in Denmark. Sweden was not among the countries included in this follow-up poll. ${ }^{17}$

15 Anti-Defamation League, “ADL Global 100. An Index of Anti-Semitism,” ‘ https://www.adl. org/adl-global-100 >.

16 Among the EU countries surveyed, only the UK, with 8 per cent of its population being antisemites as measured by this method, approaches the relatively low levels found in the Scandinavian countries.

17 The ADL 2015 Update ("Poll Finds Dramatic Decline in Anti-Semitic Attitudes in France; Significant Drops in Germany and Belgium,” 30 June 2015, < https://www.adl.org/news/press-re leases/new-poll-anti-semitic-attitudes-19-countries `), comprising a select number of countries, shows the following percentage of antisemites as defined by the ADL criteria: Hungary 40 per 
However, even if the proportion of Swedes who according to the ADL's criteria qualify as antisemites is remarkably low compared to other countries, there still exist small groups of politically organized Nazi-sympathisers in the country. Furthermore, in Denmark since around the turn of the millennium there has been an active neo-Nazi group that runs a local radio station (Radio Oasen) and at times organizes public demonstrations flying the swastika. It has also formed a political party, Danmarks Nationalsocialistiske Bevægelse (DNSB, National Socialist Movement of Denmark), and has participated in local elections in Greve, a municipality south of Copenhagen. In the 2005 municipal elections it received 73 votes, corresponding to 0.3 per cent of votes cast, and in the elections to the regional council they received 611 votes, corresponding to 0.1 per cent of votes cast. It has been estimated that in the whole country there might be around 1,000 passive and 150 active members of the DNSB. ${ }^{18}$

The largest and most active neo-Nazi organization in Scandinavia at present is the so-called Nordiska Motståndsrörelsen (NMR, Nordic Resistance Movement). It attempts to be a pan-Nordic neo-Nazi movement and in Sweden is also a political party. It was established in Sweden and claims to be active in Norway, Finland, and Denmark, and also to have members in Iceland. The NMR has been described as a terrorist organization due to their aim of abolishing democracy along with their paramilitary activities and stockpiling of weapons.

One of the NMR's favourite activities is to organize public marches and other kinds of collective demonstrations wearing uniform-style outfits, flying Nazi-inspired flags, and so on in connection with various large public cultural and political events. These have included the annual bookfair in Gothenburg and the all-inclusive political summer-rally in Almedalen on Gotland, where members of the group assaulted two pro-Israel activists on 6 July 2018. On special occasions they manage to bring out a few hundred sympathizers, but generally they seem unable to muster more than a few dozen. At times they appear threatening and resort to violent forms of action. Some of them have participated in general and local elections, but normally without gaining enough support to be represented in any government body. ${ }^{19}$ In the 2018 general elections in Swe-

cent, Poland 37 per cent, Spain 29 per cent, Italy 29 per cent, Belgium 21 per cent, France 17 per cent, Germany 16 per cent, the UK 12 per cent, and Denmark 8 per cent. Sweden was not included in this update.

18 Wikipedia, 〈https://da.wikipedia.org/wiki/Danmarks_Nationalsocialistiske_Bevægelse 〉.

19 There is one exception. In local elections in Grästorp in 2010, the neo-Nazi party, Svenskarnas parti (SvP, Party of the Swedes), received 102 votes (2.8 per cent) and a single mandate. Svenskarnas parti thus became the first Nazi party to sit in an elected assembly in Sweden since the 1940s. The party was disbanded in 2015. 
den, NMR received a total of 20,106 votes, which corresponds to 0.03 per cent of the votes cast in the country. ${ }^{20}$ Even if the NMR and other similar groups are very small in terms of numbers, they are still quite visible in the public sphere. This fact in itself causes definite alarm among Jews in Sweden.

Add to this the fact that since the 2018 general elections the third largest party in the Swedish parliament (based on slightly less than 18 per cent of the vote in the national elections) is the Sverigedemokraterna (Sweden Democrats). This party has actually grown from the same ideological roots that nourish the aforementioned Nazi-affiliated groups. However, since its creation in 1988, in parallel with its rapidly growing popular support - mainly due to its strong anti-immigration and by implication also anti-Muslim positions - it has moderated these positions and now prefers to present itself as a socially conservative and nationalist party. With its 2010 entry into the Swedish parliament, it has tried to distance itself from its white supremacist and Nazi-influenced background. As part of its attempt to pursue this transformation, several party officials have been excluded because of their either bluntly racist or antisemitic statements. Nonetheless, this did not stop one of their representatives and former second deputy speaker of the Swedish parliament, Björn Söder, from suggesting in a 2014 interview with the leading Swedish daily Dagens Nyheter, that since Sámi and Jews (for example) have dual identities, they would have to adapt and be assimilated in order to be considered Swedish in the cultural sense. This was interpreted to mean that Jews cannot be Swedish - unless they abandon their Jewish identity. ${ }^{21}$

In 2016, another leading representative of Sverigedemokraterna, its then parliamentary group leader and now economic-political spokesman, Oscar Sjöstedt, jokingly recounted how he and some colleagues, German slaughterhouse workers in Iceland, would kick sheep, pretending they were Jews, while shouting “die Juden!"22 The fact that the leadership of Sverigedemokraterna did not find this reason enough to sanction their representative might be an indication of the party's tacit acceptance of antisemitism.

To sum up on this point: There appears today to be a smaller proportion of the population in the Scandinavian countries who have classic stereotypes and

20 Valmyndigheten, ‘ https://data.val.se/val/val2018/slutresultat/R/rike/index.html 〉.

21 Niklas Orrenius, “Den leende nationalismen,” Dagens Nyheter, 14 December 2014, « https:// www.dn.se/nyheter/politik/den-leende-nationalismen/ >. In 2018 Björn Söder reiterated his statement.

22 Filip Johansson, "Här skämtar Oscar Sjöstedt (SD) grovt om judar," Expressen, 6 October 2016, 〈 https://www.expressen.se/nyheter/har-skamtar-sjostedt-sd-grovt-om-judar/ >. The video from the party where this took place is dated 2011. 
negative attitudes about Jews than among the general population in other comparable countries in the world. In Sweden the proportion of classic antisemites in the general population is lower than anywhere in the Western world. Still, there are neo-Nazi groups in the Scandinavian countries. This is particularly so in Sweden where, although small in terms of membership and very weak in attracting popular support, they have succeeded in attracting attention through their public demonstrations and actions. They thereby also succeed in creating unease among those who are and feel targeted by them - today mainly refugees and immigrants from Arab and Muslim countries and those who defend their right to stay in the country, but also Jews.

The feelings of unease and discomfort among Jews at the presence and public activities of these neo-Nazis is certainly understandable. But do these groups in fact represent a threat to the Jewish populations in Sweden and Denmark? As it seems their messages do not attract popular support, rather the opposite is true, and their demonstrations, terrible as they appear, have so far not involved violent physical attacks on individual Jews or Jewish institutions in the country. In fact, it appears that participants in these activities, largely comprising young men with criminal records involving weapons and the use of violence, ${ }^{23}$ are primarily excited by racist ideologies of Anno-dazumal and enjoy the theatrical provocation of carrying heraldic symbols reminiscent of the Third Reich. However, one can never know - and this is precisely what these groups are counting on. Still, classic antisemitism is less present in Sweden and Scandinavia in general than elsewhere.

\section{Aufklärungsantisemitismus}

Another kind of what might be perceived as antisemitism are attempts at prohibiting core Jewish practices such as brit milah (the circumcision of newborn male babies) and shechitah (the slaughter of animals according to ritual prescriptions).

The 2018 FRA survey ${ }^{24}$ asked respondents about the extent to which they had heard it suggested that circumcision and/or slaughter according to tradition-

23 Erik Wiman, Frida Sundkvist, and Frida Svensson, "Aftonbladet/SvD granskar: 58 av nazisterna dömda för brott,” Aftonbladet, 27 September 2017, « https://www.aftonbladet.se/nyheter/a/ mOBe1/aftonbladet-svd-granskar-58-av-nazisterna-domda-for-brott >.

24 The FRA survey refers to the European Union Agency for Fundamental Human Rights survey of Jewish people's experiences and perceptions of discrimination and hate crimes in European Union member states. The FRA survey was conducted in 2012 and 2018. In the references below, "FRA Report 2018" refers to Experiences and Perceptions of Antisemitism: Second Survey on Dis- 
al religious rules should be banned in their country. Almost all respondents in Denmark (98 per cent) said they had heard non-Jewish persons suggesting that circumcision or slaughter according to Jewish tradition, or both, should be prohibited. In Sweden, 77 per cent of respondents were also aware of non-Jewish people suggesting this for their country. Since slaughter according to Jewish tradition is already forbidden - in Sweden since 1937 and Denmark since 2014 the suggestions heard in both of these secular-Lutheran countries primarily concern circumcision. In none of the other ten participating EU countries are Jews confronted by such suggestions to the same extent. ${ }^{25}$ Suggestions of this kind were more rarely heard in Catholic countries like Hungary, Spain, and Italy.

In 2012, no EU member state other than Sweden had a law in effect prohibiting shechitah. Since 2012, however, legal prohibition of shechitah has also been introduced in the Netherlands, in the province of Wallonia in Belgium, and in Denmark. At the time that Denmark ratified the law in February 2014, the minister of agriculture, Social Democrat Dan Jørgensen, proclaimed that "animal rights weigh heavier than respect for religious considerations."26

In this context it should be mentioned that in recent years there has raged an intense and widespread public debate in Denmark on the circumcision of infant boys. A Danish medical doctor, Morten Frisch, launched a branch of the Intact America organization, called it Intact Denmark, and succeeded in making it into a popular movement. A journalistic internet survey indicated that slightly more than 80 per cent of the Danish population would like circumcision of infant boys to be prohibited in Denmark. A petition to the same end collected the fifty thousand signatures required to have the issue raised in the Danish Parlia-

\footnotetext{
crimination and Hate Crime against Jews in the EU (Luxembourg: Publications Office of the European Union, 2018), « https://fra.europa.eu/en/publication/2018/2nd-survey-discrimination-hatecrime-against-jews $>$.

25 FRA Report 2018, 70, tab. 8. The survey carried out in 2012 among Jews in eight EU states (Denmark was not included at the time) also showed that Jews in Sweden had been confronted with such suggestions more often than Jews in the other seven participating EU countries. At the time, 85 per cent of Jews in Sweden confirmed "In the last 12 months, having personally heard non-Jewish people suggest that circumcision and traditional Jewish slaughter should not be allowed to take place in their country."

26 Reported by Danish Radio and Ritzau News Agency, 13 February 2014. See also Andrew Brown, "Denmark's Ritual Slaughter Ban Says More about Human Hypocrisy Than Animal Welfare," The Guardian, 20 February 2014, « https://www.theguardian.com/commentisfree/andrew brown/2014/feb/20/denmark-halal-kosha-slaughter-hypocrisy-animal-welfare ’.
} 
ment. ${ }^{27}$ However, the government-appointed Ethics Council (Det Etiske Råd) had already been asked by parliament to examine the issue. On 28 June 2018, they recommended that religiously motivated ritual circumcision of boys in Denmark not be prohibited. ${ }^{28}$ On the seventy-fifth anniversary of the rescue of the Danish Jews from Nazi-occupied Denmark to Sweden, 11 October 2018, in the fully packed Copenhagen synagogue, Danish Prime Minister Lars Løkke Rasmussen stood in front of the Torah ark and faced the assembled dignitaries and members of the Jewish community, promising not to allow any religious rights or traditions to be taken away from the Danish Jews. In spite of the strong popular movement to legally prohibit brit milah, this practice has not been banned in Denmark, nor has it been in Iceland, where a similarly popular initiative to do so had been raised at the same time. ${ }^{29}$ In Sweden, too, calls have recently been made to prohibit brit milah. For example, in 2011 the former chairman of the Liberal Party and minister of social affairs, Bengt Westerberg, headed a motion to legally prohibit the circumcision of infant boys. ${ }^{30}$ Still, in spite of strong popular opposition to the practice, neither in Denmark nor in Sweden is brit milah legally prohibited - yet. The reason for this is probably that a majority of parliamentary politicians in these countries recognize how, all things considered, it would tarnish their country's image and risk having them labelled "anti-Jewish" for being the first country in the world today to prohibit this core Jewish practice. ${ }^{31}$

It should be understood that behind the strong efforts in the Scandinavian countries today to ban brit milah and shechitah are mainly humanitarian, Enlightenment-based concerns, liberal ideas about individual free choice, and ideas about what constitute "humane" animal rights. This corresponds to the priority given to rationalist reasoning and the parallel secularist disrespect for reli-

27 Anne Sofie Allarp, "Venstrefløjens sværmen for et omskæringsforbud er dybt bekymrende," Berlingske, 20 November 2018, < https://www.berlingske.dk/kommentatorer/venstrefloejenssvaermen-for-et-omskaeringsforbud-er-dybt-bekymrende >.

28 Det Etiske Råd, "Udtalelse om rituel omskæring af drenge (2018)," ‘ http://www.etiskraad. dk/etiske-temaer/sundhedsvaesenet/publikationer/udtalelse-om-rituel-omskaering-af-drenge2018 >. A minority within the Ethics Council did not agree with this conclusion.

29 See, for example, the chapter about antisemitism in Iceland by Vilhjálmur Örn Vilhjálmsson in this volume.

30 Staffan Bergström and others, "DN Debatt: 'Därför måste regeringen stoppa omskärelse av pojkar,” Dagens Nyheter, 18 November 2011, < https://www.dn.se/debatt/darfor-maste-regeringenstoppa-omskarelse-av-pojkar/ >.

31 Circumcision is also a custom among Muslims, amongst whom it is however practised differently (the subjects are usually pre-pubescent boys, not babies) and is not as fundamentally rooted in the core scriptures as it is for Jews. 
giously-based convictions that characterize much of modern Scandinavia. ${ }^{32}$ In relation to what we are discussing here we use the term Aufklärungsantisemitismus - a notion coined by the French-Italian historian Diana Pinto - to refer to this phenomenon.

However, the remarkable support for the Intact Denmark movement and many of the other rather aggressive efforts to stop the practices discussed here, cannot be attributed solely to a preference for rationalist attitudes and humanitarian concerns. Rather, much of the support for these attempts also - and this is particularly so in Denmark ${ }^{33}$ - stems from mainly blatant anti-Muslim but also (albeit not so outspokenly) anti-Jewish sentiments.

Even if it is true that the campaigns against brit milah in Denmark and Sweden build upon strong Enlightenment-based convictions (however often mixed up with misunderstood and wildly exaggerated notions about how circumcision actually affects the baby boy), and even if it is also true that this form of antisemitism - to the extent that it should even be labelled antisemitism - is not life-threatening to individual Jews, several Jewish community leaders and members do regard it as threatening the future of Jewish life in the country. ${ }^{34}$

\section{Israel-derived antisemitism}

A third form antisemitism consists in accusing and attacking Jews and Jewish institutions in the country, referring in one's actions to what one thinks the State of Israel has or is supposed to have done. We label this kind of antisemitism Israelderived antisemitism.

32 See Figure 13.1: The Inglehart-Welzel Cultural Map of the World (2008 Version).

33 Consider the history of radical anti-Muslim politics and the political atmosphere in the country.

34 Søren Ploug Lilmoes, “Jøder: Forbud mod omskæring vil slutte jødisk liv i Danmark,” Berlingske, 4 February 2015, < https://www.berlingske.dk/samfund/joeder-forbud-mod-omskaering-vilslutte-joedisk-liv-i-danmark >. Bent Melchior, "Kronik. Overrabbiner om omskæringsdebat: Vi afviser med foragt påstanden om, at vi lemlæster vores drengebørn,” Politiken, 25 February 2018, « https:// politiken.dk/debat/kroniken/art6354779/Vi-afviser-med-foragt-påstanden-om-at-vi-lemlæster-voresdrengebørn >. See Anne Cecilie Ratschau Kvium and others, "Mere end jøde: En antropologisk undersøgelse af omskæringsdebattens konsekvenser for danske jøder,” Rapport/Eksamen i anvendt antropologi (University of Copenhagen, Institut for Menneskerretigheder/Institut for antropologi, 2015), < https://beggesider.files.wordpress.com/2014/12/mere-end-jc3b8de.pdf 〉. See also Nikolaj Bøgh, “Hvad lærte vi af omskæringsdebatten,” pov. International, 10 October 2018, < https://pov.interna tional/hvad-vi-laerte-af-omskaeringsdebatten/ > 
A measure of Israel-derived antisemitism might be the degree to which Jews in Europe feel safe or unsafe because they are Jewish, due to the impact of the Arab-Israeli conflict. To the question "To what extent does the Israeli-Arab conflict impact on how safe you feel as a Jewish person in your country?" we received the following answers:

Table 13.3: The impact of the Israeli-Arab conflict on Jews' perceptions of safety in Denmark and Sweden (2018)

\begin{tabular}{lrr}
\hline & Sweden & Denmark \\
\hline A great deal & $40 \%$ & $35 \%$ \\
A fair amount & $27 \%$ & $35 \%$ \\
A little & $28 \%$ & $26 \%$ \\
Not at all & $5 \%$ & $4 \%$ \\
\hline
\end{tabular}

This table shows that approximately two thirds of the Jewish respondents in both Sweden and Denmark appear to perceive their security in their respective countries as being strongly affected by the ongoing Arab-Israeli conflict. ${ }^{35}$ Among the twelve EU states investigated, the Jews in Belgium, France, Spain, and Germany - those countries hit most severely by terrorism - perceived the impact of the Arab-Israeli conflict on their sense of security as Jews even more strongly, whereas Jews in the former communist and currently immigrant-rejecting countries Poland and Hungary did so to a considerably lesser extent. ${ }^{36}$

Another indication of Israel-derived antisemitism might be found in the answers to the question "How often do you feel that people in your country accuse or blame you for anything done by the Israeli government because you are Jewish?” To this question we received the following answers:

Table 13.4: Jews' perceptions of being held accountable for the actions of the Israeli government, in Denmark and Sweden (2018)

\begin{tabular}{lrr}
\hline & Sweden & Denmark \\
\hline All the time & $14 \%$ & $9 \%$ \\
Frequently & $20 \%$ & $28 \%$
\end{tabular}

35 In the 2012 FRA survey the proportion who felt so in Sweden was a little lower - 61 per cent. See Lars Dencik and Karl Marosi, Different Antisemitisms: Perceptions and Experiences of Antisemitism among Jews in Sweden and across Europe (London: Institute of Jewish Policy Research, 2017), 18. The entire report is available online at « https://www.jpr.org.uk/publication?id=4841 〉. 36 FRA Report 2018, 43, fig 16. 
Table 13.4: Jews' perceptions of being held accountable for the actions of the Israeli government, in Denmark and Sweden (2018) (Continued)

\begin{tabular}{lrr}
\hline & Sweden & Denmark \\
\hline Occasionally & $42 \%$ & $44 \%$ \\
Never & $26 \%$ & $19 \%$ \\
\hline
\end{tabular}

Here too, Jews living in Poland and Hungary, where according to the ADL index there is a considerably higher proportion of antisemites in the population than in the other twelve countries included in the FRA survey, ${ }^{37}$ experience being blamed for what the Israeli government is doing to a considerably lesser extent than do Jews in Sweden, with its remarkably smaller number of classic antisemites in the general population. ${ }^{38}$

Meanwhile, in 2018, Jews in all other participating countries except for the UK felt blamed as Jews for what the Israeli government was doing to a larger extent than Jews in the Scandinavian countries. ${ }^{39}$

To explore the animosity against Israel further and, if possible, also to get an idea of the extent to which such attitudes spill over onto Jews living in each of these countries, we also asked to what extent the Jewish respondents had heard non-Jewish persons in the country state, "The world would be a better place without Israel." This is reported to have been heard within the last twelve months by about one third of the respondents in all countries involved; $;^{40}$ in Denmark, 34 per cent report having heard it, in Sweden the number is 26 per cent.

Another indirect measure might be how often a Jew in each country hears the statement, "Israelis behave like Nazis against the Palestinians." In Denmark 55 per cent of Jewish respondents say that in the last twelve months they have heard this "all the time" or "frequently." In Sweden the corresponding number is 43 per cent. ${ }^{41}$ Only in the UK is this statement reported to have been heard

37 See note 16 in this chapter.

38 The answers to the same question in the 2012 FRA survey show the proportion of Jews in Sweden who felt blamed "all the time" or "frequently" because of what Israel is doing was higher in 2012 (49 per cent) than in 2018 (34 per cent). See Dencik and Marosi, Different Antisemitisms, 19.

39 In the 2012 FRA survey, Jews in Belgium, Italy, and France also reported being blamed more often than Jews in Sweden did. See Dencik and Marosi, Different Antisemitisms, 19, fig. 20. 40 Only in Hungary did the answers deviate slightly from this. There, "just" 19 per cent of respondents claim to have heard such a statement, whereas at the other end of the spectrum 40 per cent of respondents in Spain say they have come across such assertions. FRA Report 2018, 26, tab. 3.

41 FRA Report 2018, 26, tab. 3. 
just slightly less often than in Sweden, in all other countries it has been heard more often. The figure for Denmark is surpassed by higher numbers in Belgium, Germany, Spain, Hungary, and Poland.

Could it be that Jews in Scandinavia for some reason are more (or less) sensitive than Jews in other European countries in perceiving statements to be "antisemitic”? For instance, criticism of Israel? 19 per cent of Danish Jews claim they perceive non-Jews' “criticism of Israel” as being antisemitic. In Sweden, 28 per cent of Jewish respondents say this is the case. In other words, the vast majority of Jews in these two countries do not perceive criticism of Israel to be in and of itself "antisemitic." Jews in Denmark are less likely than Jews in any of the other countries included in the study to regard criticism of Israel as antisemitic. Aside from Danish Jews, only Jews in the Netherlands and Poland score lower than Jews in Sweden do - in all other countries Jews are more prone to perceive criticism of Israel as antisemitic. Denmark and Sweden are also the two countries surveyed where Jews are the least likely to regard supporting boycotts of Israel or Israelis as "antisemitic." 42

Do the answers to the questions posed about Israel-related issues indicate the degree of Israel-derived antisemitism in the countries in question? The picture is not clear. It would be misleading to assume that attacks or threats against Jews and Jewish institutions in a European country due to what Israel is doing emanate from attitudes towards Israel in the general population of that country - even if there are instances where this has also been the case. What is relevant in this context is how certain elements and specific pockets within the population react.

As one might have noticed, all the perpetrators mentioned in the two examples at the beginning of this article originate from a region of the world where antisemitism has long been part of state propaganda - not rarely modelled on Nazi-German templates. Not surprisingly then, the police investigating the two attacks described discovering a great deal of antisemitic propaganda on the perpetrators' telephones and in their social media histories. A not-too-farfetched assumption is that these perpetrators shared the view promoted in this propagan$\mathrm{da}$, that there is a semi-secret US-Israel political alliance and that Jews as such, including Jews outside of Israel and the US, are tacit agents pursuing the supposed political ambition of this alliance, both to control and destroy the world. In a similar vein, it was probably not just a slip of the tongue when one of the leading Salafist preachers in Sweden, Anas Khalifa (also known as

42 However, a majority of Jews in both Denmark (63 per cent) and Sweden (66 per cent) do perceive supporting boycotts of Israel as antisemitism. FRA Report 2018, 29, tab. 5. 
Abu Malik), ${ }^{43}$ in a note on the Israel-Palestine conflict posted on Instagram, instead of naming Israel, stated "Jews murder children, the elderly, blow up hospitals, etc." ${ }^{44}$ This is just in congruence with the widely held conspiracy theory in these circles - but not only in these circles - that all Jews are in fact party to the atrocities the State of Israel is blamed for. This conspiratorial image is, if not the most widespread, then certainly the most murderous of the different antisemitic images that today circulate in certain segments of European societies, not least in the Scandinavian countries. Thus, antisemitism in the general population is ten times more widespread in Hungary than in Sweden, ${ }^{45}$ whereas the proportion of Jews who report having been physically attacked because they are Jews, or having witnessed others being physically attacked, is higher in Sweden than in Hungary. 46

In this context one needs to be particularly careful not to generalize these facts to target Arabs or Muslims in general. There are, unfortunately, strong politically motivated forces, in particular in today's Denmark, that intentionally attempt to collectively stigmatize already marginalized groups of immigrants and children of immigrants from the Middle East living in the country. Some of these do indeed have strongly negative, not to say hostile, feelings and attitudes towards Israel. These are basically related to the ongoing Arab-Israeli conflict, and do not emanate from traditional antisemitism - although, as we have seen, they are sometimes also amplified by propaganda they have consumed.

\section{Perpetrators}

Who, then, are the perpetrators of these different antisemitisms today? The FRA surveys of 2012 and 2018 ask: "Thinking about the incident where somebody attacked or threatened you in a way that frightened you because you are Jewish -

43 At present residing in a suburb of the city of Gothenburg.

44 Quoted from Ranstorp and others, Mellan salafism och salafistisk jihadism, 135. My emphasis.

45 ADL 2014. See note 15 in this chapter.

46 Dencik and Marosi, Different Antisemitisms, 14-15, figs 15 and 16. The FRA Report 2018 does not give figures on experiences of physical attacks country by country. However, it reports, "Overall, across the 12 countries surveyed, $3 \%$ of the respondents personally experienced a physical attack because they are Jewish in the five years before the survey." FRA Report 2018, 51. A table on the same page however gives figures for the proportion of respondents who say they experienced antisemitic offensive or threatening comments in person. The proportion who did so in 2018 is higher in Sweden (19 per cent) than in Hungary (17 per cent). The proportion in Denmark is equal to that in Sweden. See FRA Report 2018, 50, fig. 50. 
who did this to you?" The respondents were given an opportunity to choose between different kinds of possible perpetrators, ${ }^{47}$ among them: "Someone with right-wing political views," "Someone with left-wing political views," "Someone with Muslim extremist views," and "Someone with Christian extremist views." The answers we received are distributed as follows:

Table 13.5: Jews' perceptions of who attacked or threatened them in incidents in Denmark and Sweden (2012, 2018)

\begin{tabular}{|c|c|c|c|}
\hline \multirow[t]{2}{*}{ Someone with } & \multicolumn{2}{|c|}{2018} & \multirow{2}{*}{$\begin{array}{r}2012 \\
\text { Sweden }\end{array}$} \\
\hline & Sweden & Denmark & \\
\hline Muslim extremist views & $40 \%$ & $34 \%$ & $51 \%$ \\
\hline Left-wing political views & $27 \%$ & $27 \%$ & $25 \%$ \\
\hline Right-wing political views & $18 \%$ & $10 \%$ & $5 \%$ \\
\hline Christian extremist views & $1 \%$ & $3 \%$ & $0 \%$ \\
\hline
\end{tabular}

As shown, the answers to the 2012 survey in Sweden (Denmark was not included in that survey) show a similar pattern as in both countries in 2018 but with somewhat sharper differences.

Of the twelve EU countries, only in Germany is the proportion of supposed Muslim extremist perpetrators slightly higher than in Sweden. Only in Italy and Spain is the proportion of supposed left-wing political perpetrators slightly higher than in Sweden and Denmark.

The 2018 FRA report states: "While the category 'someone with Muslim extremist views' is reported often, respondents frequently selected it in combination with another category. In one third of the cases of antisemitic harassment, respondents chose it together with 'someone with a left-wing political view.'”48

In no country is the proportion of supposed Christian extremist perpetrators as low as in Denmark and Sweden. With respect to supposed right-wing political perpetrators, the figures for Poland (53 per cent) and Hungary (46 per cent) differ considerably from what is the case in the other countries. Here the two Scandinavian countries occupy the middle range within the field of nations.

47 The list of options to choose from read like this: 1) Family/household member; 2) Neighbour; 3) Colleague, boss or supervisor at work; 4) Someone from school, college or university; 5) A customer, client or patient; 6) Someone with right-wing political views; 7) Someone with left-wing political views; 8) Teenager or group of teenagers; 9) Doctor, healthcare worker; 10) Police officer or border guard; 11) Public official (e.g. a civil servant); 12) Private security guard; 13) Someone with Christian extremist views; 14) Someone with Muslim extremist views.

48 FRA Report 2018, 53. 
The 2018 FRA report does not differentiate between those who are identified as uttering antisemitic comments and those who are identified as perpetrators of physical antisemitic violence and threats. However, we were able to use the database of the 2012 survey to investigate this. There it appears that the proportion who report having personally been physically attacked because they are Jewish was higher in Sweden than in all other countries except for France. Regarding antisemitic comments, the category of people with left-wing views and the category of people with Muslim extremist views are "blamed" for being the source of such comments to more or less the same degree. However, when it comes to physical violence and threats, they are much more often attributed to those with Muslim extremist views than to any of the other groups we focus on. ${ }^{49}$

A comparison between the proportion of respondents who say they have experienced antisemitic harassment in 2012 and 2018 conveys that this has on the whole remained the same over the years. However, with respect to having experienced offensive or threatening comments in person, this is reported to have increased in two of the countries, Germany and Sweden. ${ }^{50}$

Even if it is true that only a small proportion of the persons who participated in the survey report having been the victim of a violent physical attack because they are Jewish, and even if such attacks and threats do not occur frequently, the fact that they occur at all may cause a higher and more longlasting level of fear among Jews, for instance of being identified as such because of carrying or wearing something that might help people recognize them as being a Jew. This sense of fear may reach even beyond the localities where the violent antisemitic attacks have occurred, and then have a greater impact than even frequent occurrences of antisemitic comments and widespread antisemitic attitudes about Jews living in the country do.

The fact that this kind of attack is today mostly attributed to Muslim extremists and the fact that the reasons the perpetrators give for carrying out these actions are related somehow to Israel, makes Israel-derived antisemitism a major factor in contemporary antisemitism - and this is especially so in Scandinavia.

\section{Markers of Jewish identity}

Both the 2012 and the 2018 survey asked the respondents, "Do you ever avoid wearing, carrying or displaying things that might help people recognize you as

49 Dencik and Marosi, Different Antisemitisms, 28.

50 FRA Report 2018, 51. 
a Jew in public, for example wearing a kippah/yarmulke, magen David/Star of David or specific clothing or displaying a mezuzah?"

In 2012 we found the level of avoidance of carrying anything that might identify one as a Jew to be higher in Sweden than in the other participating EU counties. ${ }^{51}$ In the 2018 survey this question was put only to those respondents who in their answer to a preceding question had indicated that they at least sometimes wear, carry, or display such items. The result with that screening still shows avoidance in the Scandinavian countries to be higher than in most of the twelve participating EU countries. The country with the highest percentage to report avoiding displaying Jewish symbols "all the time" and "frequently," among those who describe themselves as sometimes carrying such symbols, is Denmark (41 per cent). The corresponding figure in Sweden is 35 per cent. In France and Germany it is almost the same, 36 per cent, whereas the feeling of needing to hide one's Jewish symbols is lower in all other countries.

Noteworthy in this context are the figures for Hungary. Hungary is the country with the highest proportion of antisemites in the general population, ${ }^{52}$ and yet it is the country where the fewest respondents who sometimes carry Jewish symbols feel the need to avoid doing so always or frequently (16 per cent).

Is there a paradox in this? Sweden and Denmark are the countries with the lowest, and Hungary is the country with highest proportion of classic antisemites in the general population. Hungary is also the country with the lowest proportion of Jews who feel they always or frequently for security reasons need to avoid carrying anything that might make them recognizable as Jews, whereas Denmark and Sweden have the highest proportion of Jews who avoid carrying symbols that might make them recognizable as Jews.

Our analysis concludes that this is not a paradox. The popular idea that it always "the same old antisemitism" that again and again pops up and "shows its ugly face" does not find support in our study. ${ }^{53}$ Of course, there are persons who at the same time, for example, hold classic antisemitic stereotypes, are very hostile towards Israel, and favour prohibiting core Jewish customs such as the circumcision of baby boys and the manufacture of kosher meat products. Our data, however, does not suggest that there should be a significant correlation between these - rather, it points to each form of antisemitism being inspired by different underlying "philosophies," being carried by different social groups, and being manifested in different ways. Hence, instead of just lumping all

51 Dencik and Marosi, Different Antisemitisms, 16, fig. 18.

52 Anti-Defamation League, “Global 100," 2014 and Update 2015. See notes 15 and 17 in this chapter.

53 Dencik and Marosi, Different Antisemitisms, 32. 
kinds of hostile remarks or actions against Jews under the label "antisemitism," we would do better, both for analytical purposes and especially in order to find remedies, to speak of three distinct antisemitisms.

\section{A specific pattern of antisemitism in Scandinavia}

Above I have presented to what extent these distinct antisemitisms are manifested today in the Scandinavian welfare states, i. e. Denmark and Sweden. Based on this we may ask: is there a specifically Scandinavian pattern of antisemitisms? If so, is this pattern just a special case among other special cases, or is the pattern instead somehow inherently related to the fact that Sweden and Denmark are probably among the most advanced social welfare states and most modernized societies in the world today? Let us summarize some main features of contemporary antisemitism in Scandinavia:

1. By European and international standards there are today outstandingly low levels of classic antisemitism in the population. Propositions like "Jews have too much power in the country," "the interests of Jews in the country differ from the rest of the population," "Jews are not capable of integrating into society," and the like are less often heard in either Denmark or Sweden than in any of the other EU states. ${ }^{54}$

2. By European and international standards there is an outstandingly high level of Aufklärungsantisemitismus, i.e. attacks on and attempts at prohibiting the practice of core Jewish customs. Virtually all Jews in Denmark and more than three quarters in Sweden have recently been confronted with such proposals, in particular about ritual circumcision (brit milah). In other EU member states such propositions are heard to a considerably lesser extent. ${ }^{55}$ Religious slaughter (shechitah) has already been prohibited in these two countries, unlike most of the other participating EU member states.

3. Israel-derived antisemitism, i.e. attacks on Jews and Jewish institutions in the country which refer to what the State of Israel is doing, appears to be a major source of unease among Jews in Denmark and Sweden. Two thirds of respondents in these countries report that the Arab-Israeli conflict impacts "a great deal" or "a fair amount" on their feeling of safety in the coun-

54 FRA Report 2018, 26, tab. 3.

55 FRA Report 2018, 70, tab. 8. 
try. ${ }^{56}$ This is the case even though the extent to which they are blamed for what Israel is doing, or confronted with statements such as "the world would be a better place without Israel," is not any greater than in the other EU member states - rather the opposite in fact. ${ }^{57}$ Is there another paradox in this? No, an explanation is to be found in the clear discrepancy that exists in Denmark and Sweden between the general population on the one hand and pockets of individuals on the other. The population on the whole is "politically correct" and quite capable of distinguishing their occasionally very harsh criticism of Israel from their behaviour towards Jews in general and from rejecting Israel's right to exist, but in the same two countries there are individuals and small groups who share an impression of Jews in general being accomplices to whatever the State of Israel does. Moreover, they are also not adverse to viewing Jews as party to an imagined evil Israel/ US plot to exploit, oppress, and destroy the world.

\section{Scandinavia as a forerunner}

When asked in a 2018 survey to assess various social and political issues, ${ }^{58} 82$ per cent of Swedish respondents rated antisemitism as a "very big" or a "fairly big” problem. Only "racism" was rated as a serious problem by a slightly larger proportion (83 per cent) of respondents. In Denmark 56 per cent rate antisemitism a "very big" or "fairly big" problem - a slightly larger proportion of Jewish respondents rated "intolerance towards Muslims" and "immigration" as serious problems in the country. Considerably fewer respondents in Denmark than in all of the other participating countries assess antisemitism as a "very big" or "fairly big” problem. The respondents in Sweden do not distinguish themselves greatly from the average respondents from other countries in this respect. Compared to the results of the 2012 survey, three countries stand out with increased proportions of respondents who say that antisemitism is "a very big" or "fairly big"

56 FRA Report 2018, 43, fig. 16. An even larger proportion of respondents in Belgium, France, Spain, and Germany - all being countries where murderous attacks on Jews that made reference to "Israel" have taken place - indicate this to be the case.

57 FRA Report 2018, 44, fig. 17.

58 The issues the respondents were asked to assess are: Antisemitism, Racism, Crime level, Unemployment, Immigration, Intolerance towards Muslims, Government corruption. Antisemitism is regarded as being among the three most serious issues by respondents in all of the participating countries except for Italy and Spain. In both of these countries "Unemployment" and "Government corruption" are assessed to be more of a problem. FRA Report 2018, 16, tab. 1. 
problem - the UK, Germany, and Sweden (increased by 27, 23, and 22 percentage points, respectively)..$^{59}$

Can these results be understood as somehow reflecting the social and political conditions in each of these countries? First of all, we can establish that respondents in Denmark and Sweden differ in their assessments of antisemitism as a problem in their respective countries. About twice as large a proportion of respondents in Sweden than in Denmark perceive antisemitism to be "a very big problem." ${ }^{60}$ Historical national self-images probably play a role here. In Denmark one proudly recalls the rescue of the country's Jews in October 1943. Denmark in the eyes of the Danes, and also in the eyes of the Jews living in Denmark, was never an antisemitic country - quite the opposite! ${ }^{61}$ In Sweden, on the contrary, there is a certain self-blame for having endorsed a "J" being stamped in the passports of Jews trying to escape Nazi Germany, whereby they could more easily be refused entry into Sweden. This self-blame also results from the fact that Sweden, although neutral during the Second World War, allowed the German Wehrmacht to use its territory for troop transports.

But besides historical facts, more contemporary factors also distinguish the countries. In Sweden, clearly neo-Nazi movements have in recent years been very active and visible on the public scene. This is not the case in Denmark. In Sweden a populist political party with obvious neo-Nazi roots, Sverigedemokraterna, is strongly represented in the Parliament. Members of this party have repeatedly been caught making antisemitic remarks and gestures. In Denmark, a xenophobic populist party, Dansk Folkeparti (Danish People's Party), has a similarly very strong standing in the parliament, however it is not stained by similar Nazi tendencies. Add to this huge differences between the countries with respect to immigration and immigration policies. Whereas in recent years Denmark, largely under the influence of Dansk Folkeparti, has pursued a very restrictive line regarding immigrants and refugees from the Middle East being able to settle in the country, Sweden has been much more open and generous in this respect. As shown in the first section of this article, the number of immigrants and refugees from the Arab and the Muslim world in general received in Sweden is much higher than in Denmark. Even if this in itself is not related to acts of antisemitism, the presence in the country of members of these groups may, rightly or wrongly, be perceived as a latent threat to Jews in the country. The magnitude of such a perception may very well be related to the relative size of the groups

59 FRA Report 2018, 18.

60 FRA Report 2018, 17, fig. 1.

61 See the chapter by Sofie Lene Bak in this volume. 
in question, in particular of young marginalized Arabs and Muslims, living in one's neighbourhood or the country in general. The infamous events that have taken place in the city of Malmö in recent decades may serve as a case in point illustrating this. ${ }^{62}$

\section{The Shoah and its consequences for antisemitism in Scandinavia}

This article deals with antisemitism in Europe, specifically Scandinavia, after the Holocaust - the Shoah (השואה, "calamity”) or Khurbn Eyrope (חורבן אייראָּפע, "destruction of Europe") as Jews themselves prefer to call the murder of millions of Jews in Europe in the years 1939-45. The first thing to observe in this context is how the Shoah itself, and experiences and knowledge about it, have fundamentally changed the position of, and attitude towards, antisemitism in Europe. The next thing to observe is the changes brought about by the general processes of modernization that in the decades since the Second World War have radically transformed European societies.

One effect of the collapse of the Third Reich has been the total discrediting of its fundamental ideas in the eyes of the postwar populations in Europe. "Race" is no longer a socially acceptable concept when it comes to describing and analysing social issues and societies. The radically increased mobility between nations and peoples that has taken place in recent decades in Europe has also made most European societies much more ethnically mixed and cosmopolitan than they used to be. After the Shoah ideas of "human rights" and "the equal value of every human being" have become codified in international conventions and are also hegemonic in many countries - today this is particularly so in Sweden. On the whole, both "race" as a concept and "racism" as an ideology and perspective have largely lost their explanatory power and by that also the place they previously held in public affairs. Even if antisemitism based on racist ideas and assumptions is still alive and kicking as a significant aspect of fringe

62 By Swedish standards, a relatively large number of immigrants from the Middle East live in social housing in Malmö in areas such as Rosengård, from where several of the many antisemitic incidents in the city are thought to have emanated. Brottsförebyggande rådet (BRÅ), "Hatbrott 2016: Statistik över polisanmälningar med identifierade hatbrottsmotiv och självrapporterad utsatthet för hatbrott," Rapport 11 (2017), « https://www.bra.se/download/18.4c494ddd15e9438f8ada9786/1513175214923/2017_11_Hatbrott_2016.pdf >. See also "Antisemitism in Sweden, section 1.6. Situation in Malmö since 2009,” Wikipedia, « https://en.wikipedia.org/wiki/Antisemitism_ in_Sweden >. 
neo-Nazi groups in some European countries, including Sweden, the political and social roles played by "race" in social affairs seem to be fading out, especially in Scandinavia.

Jews throughout history have - though not everywhere and not always been identified by race, as they were in Nazi Germany. In several countries, including Scandinavia, traditionally Jews have officially only been identified by religion. Since about the mid-nineteenth century, here they have formed what they called "communities of Mosaic believers" (Det Mosaiske Troessamfund in Denmark and Mosaiska Församlingen in Sweden) - so-named as a kind of counterpart to the "communities of Christian believers" into which all other citizens in the country at that time were born and had to belong. ${ }^{63}$ Today the ethnic and cultural aspects of Jewishness have become more central and the former "communities of Mosaic believers" in both countries have adopted the term "Jewish communities." However, there is a significant difference. Since the year 2000, Jews are one of five groups ${ }^{64}$ officially acknowledged as being a "national minority" in Sweden. In Denmark they are still officially regarded as mainly a religious minority.

Fuelled by the emergence of several private Muslim schools, in recent years voices have been raised to prohibit schools based on religion. In Denmark this has focussed entirely on Muslim schools. In Sweden the Left, Social Democratic, and Liberal political parties have proposed a total prohibition of all religious schools, a proposal subsequently modified to apply only to the establishment of new religious schools.

In Denmark there is just one Jewish school, Carolineskolen. Attendance at this school requires that at least one parent be a paying member of a recognized Jewish congregation in Denmark. In Sweden there is also just one Jewish school, Hillelskolan. This is a Jewish school however it is not defined as a "religious" school. Since the Jews in Sweden have "national minority" status, the Jewish school in Sweden is regarded as a national minority school. This means the school respects Jewish holidays, teaches about Jewish history and culture, etc. but is not permitted to include Jewish religious practices in the school curriculum. In principle, admittance to this school is open to anyone who wants to study there.

63 The rationale behind this goes: as the Christians have their Christ, Jews have their Moses otherwise all belong to the same Swedish/Danish nation. The difference between Jews and other Danes or Swedes should be attributed solely to religion.

64 The other groups are the Sámi, Roma, Swedish-Finnish, and the regionally defined Tornedalians. Along with this, Yiddish is also an officially acknowledged minority language in Sweden, implying support and funding from the state. 
Looking at the social role of religion in a historical perspective, it is clear that in the wake of modernization religion has lost much of its social significance in Europe, and this is especially so in Scandinavia. Only in recent years, fuelled in part by the immigration of large numbers of Muslims, has religion once again become an issue of public concern and debate. In surveys carried out around the turn of the millennium, when affiliated members of the Jewish communities in Sweden were asked "How do you regard the Jewish group in Sweden?" not even 5 per cent chose the option "primarily as a religious group," whereas just over 65 per cent chose the option "primarily as a part of the Jewish people." ${ }^{65}$ When asked about their relationship to practising the Jewish religion, just 3 per cent of the affiliated members of the Jewish communities in Sweden describe themselves as "orthodox," whereas 44 per cent characterize themselves as "traditional but not orthodox," 26 per cent say they are "liberally Jewish,” 28 per cent say they are "just Jewish," and just over 9 per cent say they "do not practise religion at all." 66 (In Denmark no equivalent study has been carried out as of yet.)

On the whole, Jews in Sweden and Denmark are very well integrated in society and quite assimilated into the modern Western lifestyle. Religion today plays a subordinate role in the two Scandinavian societies and it would seem this is also largely the case among their Jewish populations. Based on the relative social unimportance of religion in these societies, one would expect antisemitism emanating from concern with religious matters - as it has historically when Jews have been accused of being murderers of Christ, deniers of the Messiah, worshippers of an evil God, etc. - would have faded out. In Sweden and Denmark today, rationality and secularism are preferred values guiding public affairs and colouring what is valued in public debate. In fact, in these countries there is not only a certain hostility towards bringing religion into the public sphere, but also towards religion as such.

Yet paradoxically enough, this condescending view of religion has led to an increased preoccupation with certain of the core Jewish religious practices. In a previous section of this article we introduced the notion of Aufklärungsantisemitismus. This particular category of anti-Jewish attitudes - objecting to and denying Jews the right to practise some of their core Jewish customs such as brit milah and shechitah - is, it would seem, mainly driven by liberal Enlightenment-based ideas about each individual's right to choose for themself and ideas about what

65 Dencik and Marosi, Different Antisemitisms, 36, tab. 4.3. Close to 25 per cent chose the option "both aspects to the same extent," and slightly less than 6 per cent did not know how to answer the question.

66 Dencik and Marosi, Different Antisemitisms, 26, tab. 3.1. 
is "humane" for animals. But the energy put into these efforts certainly also emanates to a considerable extent from a desire to counter anything "Muslim" and this is especially so in Denmark. The remarkably successful Intact Denmark movement - the idea being that the male's penis should be kept "intact" - also builds to some extent upon suppressed but still clearly sexual obsessions and classic antisemitic energies, nourished by a long history of antisemitic prejudices.

After all, "race" is no longer a concept underlying the antisemitism of Denmark or Sweden, nor are Jews today on the whole regarded in these countries as being particularly deviant, "strange," or "foreign." Combining three different indices of how "strange" Jews are perceived to be in their respective countries, showed that Jews in Sweden on all three indices are seen as "strange" in their country to a lesser extent than they are in any of the other seven countries involved in the 2012 FRA survey. ${ }^{67}$

\section{Israel and antisemitism in Scandinavia}

In the increasingly multicultural ${ }^{68}$ and highly modernized welfare societies of Sweden and Denmark, neither "race" nor "religion" are socially significant today, nor do they constitute a major basis for the antisemitic attitudes, remarks, or actions that still occur in these countries. Yet according to 91 per cent of Swedish and 85 per cent of Danish respondents, such attitudes, remarks, and actions have in fact increased over the past five years in their respective countries ${ }^{69}$ what then is the source of this antisemitism, and what is it that lends energy to the ways in which it manifests itself?

The answer is: Israel. Or rather, the reactions of certain groups to how they perceive Israel, and what they perceive the State of Israel is doing. Israel is involved in international conflicts and many controversies. People, including

67 Dencik and Marosi, Different Antisemitisms, 13, fig. 14. Jews are seen to be most "strange" in Hungary, followed by Latvia, France, Belgium, Germany, Italy, and the UK (in that order).

68 See the migration figures in the introduction to this text. In Denmark "multiculturalism" is officially deemed to be something the country should avoid, whereas in Sweden it is officially acknowledged that the country is today a multicultural society. Even if there are different evaluations of multiculturalism and cosmopolitism as ideologies, the social reality "on the ground" is that in both of these countries there live increasing numbers of people from different nations and cultural, linguistic, and religious backgrounds. In that sense they are as a matter of fact today both multicultural and cosmopolitan countries.

69 See FRA Report 2018, 19-20, fig. 2. 
Jews, can sometimes be very critical of actions undertaken by the Israeli state, of the politics its government pursues, of what goes on within and around the country, and so forth.

There are several institutions and groups who today speak of a, or even the, new antisemitism. ${ }^{70}$ By this concept one attempts to identify a new form of antisemitism that has developed in the late twentieth and early twenty-first centuries. The "new antisemitism" is supposed to manifest itself mainly as opposition to Zionism as an ideology and as criticism of the State of Israel. Those who employ the concept "the new antisemitism" generally posit that much of what various individuals and groups today purport is criticism of Israel and Zionism, is in fact antisemitism hiding behind the cover of anti-Zionism. "Anti-Zionism is the new antisemitism" reads the proposition. ${ }^{71}$ However, it appears the proposition that the old antisemitism nowadays "hides behind anti-Zionism" reverses what is actually going on. ${ }^{72}$ According to our observations anti-Zionism is the primary reaction. Most of the violent attacks on individual Jews and Jewish institutions in Europe carried out by different groups of terrorists is a consequence of their conspiratorial image that Jews as such are tacit agents of, or accomplices to, Israel's political actions and ambitions, and as such are legitimate targets in their fight against "Zionism."

This in effect is a kind of adopted or derived antisemitism, today flourishing in certain quarters in Europe, not least in some rather well-defined circles in Denmark and Sweden. Today its presence in these societies in and of itself is per-

70 See Brian Klug, "The Myth of the New Anti-Semitism," The Nation, 15 January 2004; Brian Klug, “Interrogating 'New Anti-Semitism,"” Ethnic and Racial Studies 36, no. 3 (2013): 468-82; Michael Lerner, "There Is No New Antisemitism," The Baltimore Chronicle, 2 February 2007; and Antony Lerman, "Jews Attacking Jews," Ha'aretz, 12 September 2008.

71 Writing in 1973 in the publication of the American Jewish Congress, Congress Bi-Weekly, the Foreign Minister of Israel, Abba Eban, identified "the new anti-Semitism," saying: "[R]ecently we have witnessed the rise of the new left which identifies Israel with the establishment, with acquisition, with smug satisfaction, with, in fact, all the basic enemies ... Let there be no mistake: the new left is the author and the progenitor of the new anti-Semitism. One of the chief tasks of any dialogue with the Gentile world is to prove that the distinction between anti-Semitism and anti-Zionism is not a distinction at all. Anti-Zionism is merely the new anti-Semitism. The old classic anti-Semitism declared that equal rights belong to all individuals within the society, except the Jews. The new anti-Semitism says that the right to establish and maintain an independent national sovereign state is the prerogative of all nations, so long as they happen not to be Jewish."

72 On this point see also Peter Beinart, "Debunking the Myth that Anti-Zionism is Antisemitic," The Guardian, 9 March 2019, < https://www.theguardian.com/news/2019/mar/07/debunkingmyth-that-anti-zionism-is-antisemitic >. 
ceived as, and does in fact constitute, more of a threat to Jews wherever they live than any of the other contemporary antisemitisms we have described.

Critical stands on what Israel is doing may very well be both warranted and legitimate. Often they are. As has been observed all too often in recent years, frivolous use of the notion of antisemitism ultimately hollows out its usefulness in describing and pinpointing what really constitutes a danger to Jews as well as to the idea of human rights in general. Antisemitism is too serious a matter to be misused for narrow political purposes, for instance by spokespersons for Israel or Zionist interests.

However, what does make opposition to "Israel" a source of antisemitism is the propensity to presuppose an inherent link between Israel and individual Jews and Jewish institutions in Europe. Of course, most people in Sweden and Denmark can distinguish very well between "Israel" and individual Jews and Jewish institutions in the country. Statistics show, however, that when Israel, as is often the case, comes to the fore in the news, antisemitic attacks on Jews and Jewish institutions, regardless of their personal stands on the events in Israel, increase. "In the past two decades, antisemitic attacks in Europe have generally peaked in line with tensions in the Middle East. 'They were essentially the Israeli-Palestinian conflict, imported,' said Marc Knobel, a historian at the Crif umbrella group for France's Jewish organizations. 'Rather than attacking Israelis, people went for Jews." "73 The propensity to construct and believe in the link that leads certain individuals and groups to attack Jews because of how they perceive the State of Israel and what Israel is doing, normally lies with only a few groups, albeit specific ones: Muslim extremists with jihadist orientations, and some leftists, mainly extremist ultra-left action groups. ${ }^{74}$ In both of these groups, as is the case also among right-wing extremists, there prevails an ambition to "explain" what goes on in the world by identifying an "ultimate" actor or force that can be blamed for being the agent behind it all.

However, when heated situations come to a head, or just become very complex and ambiguous, people who normally are perfectly able to think clearly and make distinctions also tend to regress to oversimplified and more or less conspiracy-like thought structures. This is why at times we may also encounter persons who are normally not at all antisemitically inclined, and at times even wider sectors of public opinion, resorting to what we have described as Israel-de-

73 John Henley, “Antisemitism rising sharply across Europe, latest figures show,” The Guardian, 15 February 2019, 〈 https://www.theguardian.com/news/2019/feb/15/antisemitism-rising-sharplyacross-europe-latest-figures-show >. See also Svenska kommittén mot antisemitism (SKMA), "What is antisemitism?" 〈https://skma.se/about-antisemitism/ >.

74 FRA Report 2018, 53. 
rived antisemitism, even if in much milder and far more tame forms than the extremist groups do. ${ }^{75}$

The Swedish historians Stephane Bruchfeld, Mikael Byström, and, in particular, Karin Kvist Geverts have each elaborated on the concept "the antisemitic background noise" (det antisemitiska bakgrundsbruset) to describe how a kind of unsharply articulated or latent antisemitism rattles in the background of political processes and debates. Bruchfeldt introduced the concept in an article as early as $1996^{76}$ and referred back to it in his dissertation published in $2006 .^{77}$ Kvist Gevert made it a key concept in her dissertation of the same year ${ }^{78}$ and drew a parallel to the notion of "white noise" as used in e.g. statistics, psychology, and audiology to describe what is constantly in the background but in a pitch that tends to escape the untrained human ear.

Another Swedish historian, Lena Berggren, has made the following reflections: ${ }^{79}$

In my thesis ${ }^{80}$ on what antisemitism articulated in the border area of Swedish ultra-nationalism looked like I could show that antisemitism was not of one single kind - even in this ideological environment - and that the most crude antisemitism was expressed by persons who were in fact not organized fascists. I could also demonstrate that in my material there were strong indicators that it was not national socialism that was the gateway to antisemitic attitudes, but rather the cultural nationalism and neo-romantic currents that had been strong in Sweden since the late nineteenth century, currents that were also present in the early phases of the Swedish race biology.

75 The idea that Jews in general are in fact related to and supporters of the State of Israel, and thus also are to be blamed for atrocities carried out by that state, is apparent in statements and actions taken by the former Social Democratic chairman of the Malmö city council, Ilmar Reepalu. See the interview in "Reepalu: Israel har skapat en 'varböld," Skånska dagbladet, 27 January 2010, 〈 https://www.skd.se/2010/01/27/reepalu-israel-har-skapat-en-varbold/ >.

76 Stéphane Bruchfeld, "Löjliga anklagelser - om den s k historierevisionismen," Historisk Tidskrift 1 (1996): 120-47.

77 Mikael Byström, En broder, gäst och parasit: Uppfattningar och föreställningar om utlänningar, flyktingar och flyktingpolitik i svensk offentlig debatt (Stockholm: Stockholms Universitet, 2006). 78 Karin Kvist Geverts, Ett främmande element i nationen: svensk flyktingpolitik och de judiska flyktingarna 1938-1944, Studia historica Upsaliensia 233, Uppsala University Holocaust and Genocide Studies Publications 2 (Uppsala: Acta universitatis Upsaliensis, 2008).

79 Lena Berggren, "Om antisemitismen och forskarens ansvar," ' https://www.blogg.umu.se/ forskarbloggen/2017/04/om-antisemitism-och-forskarens-ansvar/ >.

80 Lena Berggren, Blodets renhet: En historisk studie av svensk antisemitism (Malmö: Arx Förlag, 2014). 
Parallel to this thesis two others on Swedish antisemitism were published. In his thesis En jude är en jude är en jude..., ${ }^{81}$ Lars M. Andersson convincingly showed how prominent, to say the least, antisemitism was in the Swedish comic press during the first decades of the twentieth century. Henrik Bachner demonstrated in razor sharp clarity in his thesis Aterkomsten ${ }^{82}$ that antisemitism in Sweden survived 1945. Later works by Håkan Blomqvist ${ }^{83}$ and several others have further increased our knowledge about Swedish antisemitism and contributed to documenting empirically that antisemitism was far from only originating within national socialist discourse but was also broadly represented among the political left. "The antisemitic background noise" is still there in Denmark and Sweden. But this "noise" is today not just "white." Rather, it has become inked with the blue stripes and star of the Israeli flag.

\section{Conclusion}

So here we are: antisemitism based on racial prejudices is losing ground, and so is antisemitism based on religious convictions. Classic antisemitic prejudices no longer have a strong popular resonance in Denmark and Sweden. Yet antisemitic attacks still occur, and they may even be on the rise. Within the Jewish population in the two countries there is a sense of increasing insecurity. Fear of possible Israel-derived attacks on Jews and Jewish institutions is the main cause of this sense of insecurity, and such attacks are also the overall dominant factor behind contemporary antisemitism in these two modern Scandinavian welfare states.

In order to understand the position and character of antisemitism in these countries, it is necessary to recognize that the social reality of Jews living in the Western world has undergone a fundamental and rapid transformation in the last century, not only because of major events in Jewish history itself such as the Shoah and the establishment of the State of Israel - but also, and mainly, because of the impact of ongoing sociological modernization processes, with all the associated implications in terms of the rationalization, secularization, and individuation of social life.

81 Lars M. Andersson, En jude är en jude är en jude...: Representationer av "juden" $i$ svensk skämtpress omkring 1900-1930 (Lund: Nordic Academic Press, 2012).

82 Henrik Bachner, Återkomsten: Antisemitism i Sverige efter 1945 (Stockholm: Natur och Kultur, 2004).

83 Håkan Blomqvist, Myten om judebolsjevismen: Antisemitism och kontrarevolution (Stockholm: Carlssons, 2013). 
Rationalization implies that efficiency, utility, profitability, and rational justification of attitudes and actions become superior considerations in all spheres of life.

Secularization implies that anything, not least established values and religious traditions, can and should be subjected to critical questioning as to why these customs, rules, and traditions should prevail.

Individuation means that individuals have become singled out socially, "disembedded" from their social backgrounds, as the leading British sociologist Anthony Giddens puts it, ${ }^{84}$ and are nowadays - ideally - treated only as an individual person, not as a person belonging to or representing any ascribed collectivity, be it via kinship, ethnic belonging, religious affiliation, or anything else of the kind. The idea of equal rights for all, regardless of race, sex, or social background, has become widely accepted as a new and fundamental value in the Western world - especially so in the modern Scandinavian welfare states. ${ }^{85}$

In the wake of the breakthrough of Enlightenment ideas in Europe in the eighteenth century, the processes of rationalization, secularization, and individuation have been operating in Western societies and have brought about dramatic changes penetrating virtually all aspects of life. Scientific thinking, technological innovations, economic growth, ideas of democracy, the rule of law, human, individual, and equal rights, increasing respect for "the other" - all of this and much more of what today is usually described as "progress" has both caused and characterized what is meant by the modernization of societies.

The Scandinavian welfare states are according to various criteria probably the most thoroughly modernized countries in the world. The very comprehensive global research project World Values Survey (WVS) explores people's values and beliefs. Issues such as support for democracy, tolerance of foreigners and ethnic minorities, support for gender equality, the role of religion and changing levels of religiosity, the impact of globalization, attitudes towards the environment, work, family, politics, national identity, culture, diversity, insecurity, and subjective well-being are being monitored. ${ }^{86}$ Based on these and other measures and indicators, and further analysis of WVS data, two leading political scientists, Ro-

84 Anthony Giddens, The Consequences of Modernity (Cambridge: Polity, 1990), 21-29.

85 Lars Dencik, “'Homo Zappiens': A European-Jewish Way of Life in the Era of Globalisation,” in Turning the Kaleidoscope: Perspectives on European Jewry, ed. Sandra Lustig and Ian Leveson (New York: Berghahn Books, 2006), 79-105.

86 The World Values Survey is a global network of social scientists studying changing values and their impact on social and political life. It is led by an international team of scholars, with the WVS Association and WVSA Secretariat headquartered in Vienna, Austria, < http:// www.worldvaluessurvey.org/ >. 
nald Inglehart and Christian Welzel, found that there are two major dimensions of cross-cultural variation in the world. Based on this they produced a "cultural map" of the world where countries are plotted along two orthogonal axes. The vertical (y) axis plots countries according to their relative positions with respect to Traditional vs Secular-Rationalist Values, the horizontal (x) axis plots countries' relative position with respect to Survival vs Self-expression Values. ${ }^{87}$ The map looks like this:

As can be seen, Sweden is to be found in the upper right corner of this map, which means it is the most secular-rational country in the world, but also the country where the most space is given to self-expression values. In other words, it is simultaneously the most modern and also the most individualistic of all countries in the world. Furthermore, as can be seen, the two other Scandinavian welfare states, Denmark and Norway, follow suit.

As we have noted throughout this article, the pattern of antisemitisms in Sweden and Denmark differs from how antisemitism manifests itself elsewhere in Europe. In the Scandinavian countries there is today less classic antisemitism, more Aufklärungsantisemitismus, and a relatively stronger presence of Israel-derived antisemitism.

One may conclude that this is just one exceptional case among other patterns of antisemitism. However, in our analysis this Scandinavian pattern of antisemitisms is rather closely related to the relatively highly developed processes of modernization in the Scandinavian countries on the one hand and the relatively strong presence of recently arrived immigrants from the Middle East on the other.

There is no way to predict how the world will develop. However, considering the way the processes of modernization operate it is not a far-fetched assumption that in due time other countries in Europe will follow a similar trajectory. Rationalization, secularization, and individuation will also penetrate these societies and weaken notions of "race" and "religion" as springboards for antisemitism. At the same time, the very same values will strengthen tendencies to what has here been termed Aufklärungsantisemitismus. And if societies are not willing or not able to integrate their immigrants, if for instance marginalization and condescending treatment of Muslim inhabitants continues or even grows, as in Denmark today, Israel-derived antisemitism can also be expected to continue or grow.

An apparently strange phenomena discussed in places - also in this volume - refers to the concept of "antisemitism without Jews." This has been observed in

87 The Inglehart-Welzel Cultural Map recreated by Koyos - Own work, CC BY-SA 3.0, < https:// commons.wikimedia.org/w/index.php?curid=5459884 >. 


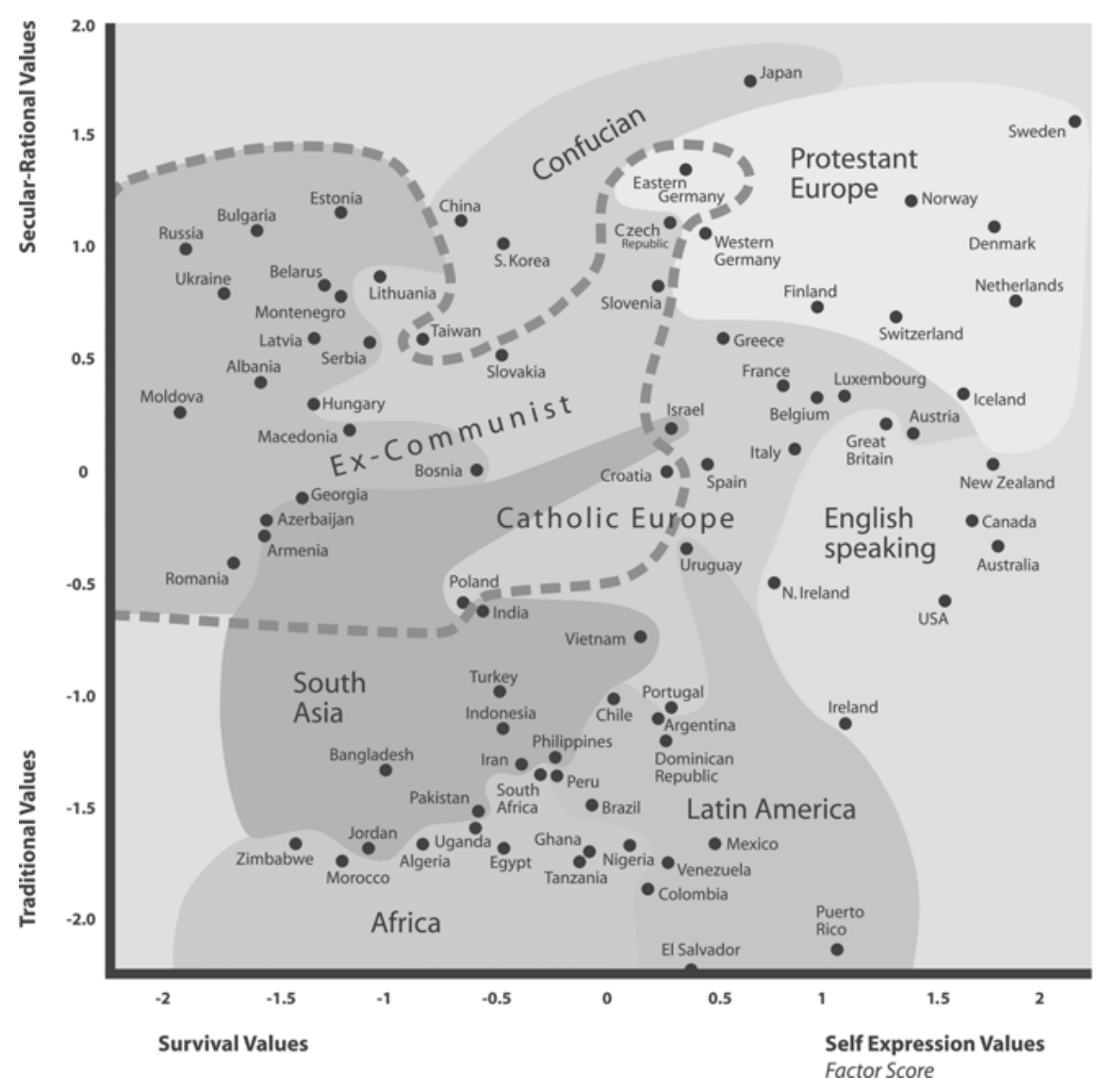

Figure 13.1: The Inglehart-Welzel Cultural Map of the World (2008 Version). Wikipedia Commons (public domain).

countries where virtually no Jews have ever lived, e.g. Japan, and in countries where virtually no Jews live anymore, e.g. Poland. In the Nordic countries, as demonstrated at the beginning of this article (see the section on Demographics) the presence of Jews in the population has historically been very marginal, although it should be kept in mind that in Sweden, in contrast to all other European states, the Jewish population has actually almost tripled as a consequence of the Shoah. However, even if, in Sweden at least, antisemitism cannot as such be regarded as being "without Jews," one element of our analysis makes for "antisemitism without Jews" being a highly viable phenomenon for as long as we can foresee: Israel. 
One could think that without living Jews around, the sociological modernization processes would make classic antisemitism obsolete and make Aufklärungsantisemitismus irrelevant. But as long as the State of Israel prevails and acts on the political scene there will still remain one source for continued and threatening antisemitism: Israel-derived antisemitism. Paradoxical as it may seem, this kind of antisemitism can thrive even if the targets can no longer be local living Jews. In such cases someone else can just be singled out as an "objective agent" of Israeli and by implication even "Jewish" interests.

In this perspective, what we in this article have been able to note about the patterns of antisemitism in Denmark and Sweden, might not just be one exceptional case, but rather a preview of what antisemitisms in twenty-first century Europe might come to look like. 